\title{
Welfare State Attitudes to the Male Breadwinning System: The United States and Sweden in Comparative Perspective
}

\section{LENA SOMMESTAD*}

Human reproduction is a basic economic activity in every society. It includes activities such as maternal care, childcare, old age provision, poor relief, healthcare, and labour protection. In pre-industrial times, human reproduction was typically a part of kin-based household economies, but since the onset of industrialization two new institutional solutions have developed: the male breadwinning system and the welfare state. ${ }^{1}$

In historical perspective, the male breadwinning system builds on earlier household-based reproductive practices. It constitutes a basically private approach, marked by a female specialization in reproductive activities. According to male breadwinning ideology, men are primarily providers, responsible only for professional and financial aspects of the reproductive process. Married women, by contrast, are supposed to perform most of the work needed to reproduce the population. This work is unpaid and consequently married women are economically dependent on their husbands.

In practice, of course, male breadwinning systems diverge more or less from the strict gender division of labour prescribed by male breadwinner ideology. In particular, married women have often participated in breadwinning activities. More importantly, however, there is no industrialized society in which the male breadwinning system has been capable of carrying out the national reproductive process without public support. Along varying institutional paths, public institutions have intervened to take on responsibility for smaller or larger parts of the national reproductive burden. Welfare states have taken shape.

Welfare states have differed markedly in their attitude to the male breadwinning system, and although all welfare states have modified their adherence to the male breadwinning model in recent decades, important distinctions remain. In residual welfare states, such as the United States, the guiding principle has been to rely as much as possible on private, male breadwinning arrangements. Social spending has been limited and access to benefits largely gendered. Other, more extensive welfare states, such

- I am grateful to Christina Bergqvist, Daniel A. Cornford, Angélique Janssens, Bo Malmberg. Sally McMurry, Lynn Karlsson, Grey Ostenid, Wendy Sarvasy and Ulla Wikander for helpful comments and to Michael Brown and Görel Granström for valuable information.

'A.F. Robertson, Beyond the Family. The Social Organization of Human Reproduction (Cambridge, 1991), pp. 1-5.

International Review of Social History 42 (1997), Supplement, pp. 153-174 
as Germany and the Netherlands, have also relied heavily on the male breadwinning system but, in contrast to the United States, these welfare states have more actively supported male breadwinning practices. This active support has resulted in strong male breadwinner states with gendered social rights. Finally, in a few cases, welfare state development has partly served to undermine citizens' dependence on the male breadwinning system. Sweden is a case in point. In the post-war Swedish model, the costs of human reproduction were increasingly socialized, and a dual breadwinner norm was explicitly established in the early 1970s. At this time, the government initiated separate taxation, a new and generous programme of parental leave, and a rapid expansion of public day-care provision. Today, the only major entitlement that is still provided exclusively to women in their capacity as wives, widow's pensions, is gradually being phased out. ${ }^{2}$

How can we explain the fact that most welfare states have continued to rely on the male breadwinning system, while Sweden has not? In this article I suggest that we need to study early welfare state institutionalization, up to the 1930s, in order to understand the distinctiveness of the Swedish case. I argue that nationally specific economic and demographic conditions during this formative period shaped distinctive social policy solutions, and that these solutions in tum affected subsequent welfare state developments. In order to support my argument, I compare Sweden with the United States, a contrasting case in Western welfare state history.

My discussion centres on three main aspects of social policy: the public inclination to intervene in the sphere of reproduction, the gendered structures of social provision, and state attitudes towards gainful work by single mothers and married women. Tax policies are not considered. In the American case, I focus on the European American population, whose representatives were predominant in shaping social policies and defining national goals. My analysis ends with the 1930s, when Roosevelt's New Deal and the social democratic breakthrough in Sweden initiated a new era.

\section{THE MALE BREADWINNING SYSTEM AND THE RISE OF WELFARE STATES}

It has been a widespread assumption in feminist welfare state research that the early European welfare states were designed to fit and to reinforce the male breadwinning system. Only recently has this assumption been

2 Jet Bussemaker and Kees van Kersbergen, "Gender and Welfare States: Some Theoretical Reflections", and Anette Borchorst, "Welfare State Regimes, Women's Interests and the EC", both in Diane Sainsbury (ed.), Gendering Welfare States (London, 1994), pp. 844; Jane Lewis (ed.), Women and Social Policies in Europe. Work, Family and the State (Aldershot, 1993), pp. 15-20; and Diane Sainsbury, Gender, Equality and Welfare States (Cambridge, 1996), pp. 9-14, 49-72 and 190-194. 
challenged, primarily with reference to developments in France and Sweden. Susan Pederson has suggested, for example, that the French welfare state is built on a "parental" rather than on a male breadwinner welfare logic, and Diane Sainsbury has shown that Sweden early developed social policies that were at odds with the male breadwinner model. As regards the rise of the distinctive American welfare state, the early period in particular has evoked different interpretations. Theda Skocpol describes American social policies up to the 1920 s as "maternalist" in character, in contrast to the more "paternalist" welfare states of contemporary Europe. By contrast, studies by Linda Gordon and Alice Kessler-Harris confirm the view that the early American welfare state, like major European welfare states at the time, was built in accordance with a male breadwinner model. However, institutional solutions in this residual American welfare state differed from models of social provision prevalent in Europe. ${ }^{3}$

A pioneering theoretical contribution on the historical relationship between welfare states and the male breadwinning system was presented by Jane Lewis in $1992 .^{4}$ Lewis classifies a number of European welfare states according to the strength of the male breadwinner model. Her scheme includes strong male breadwinner states (Britain and Ireland), "modified" male breadwinner states (France), and "weak" male breadwinner states (Sweden). Lewis points to the fact that modern welfare state formation coincided with a historical period when the ideology of male breadwinning was particularly strong, and she argues that all welfare states have subscribed to some degree to the idea of a male breadwinner model.

How, then, can the development of different state attitudes to male breadwinning practices be explained? Lewis does not deal explicitly with this question, but she does point to distinctive features in Irish and British as opposed to French and Swedish welfare state history. Her analysis of France and Sweden, where the male breadwinner model is "modified" or "weak", is of special interest. In the French case, economic and demographic factors stand out as particularly important. On the basis of broad scholarly agreement, Lewis observes that pro-natalism and high female labour force participation, in particular in the large rural sector, led at an early stage to the modification of the male breadwinning system in France. As regards the rise of the weak Swedish male breadwinner state, by contrast, Lewis gives less weight to economic and demographic factors.

${ }^{3}$ Linda Gordon, Pitied But Not Entitled. Single Mothers and the History of Welfare 1890 1935 (New York, 1994); Alice Kessler-Harris, "Gendered Interventions: Exploring the Historical Roots of U.S. Social Policy", The Japanese Journal of American Studies, 5 (1993-1994); Susan Pederson, Family, Dependence, and the Origins of the Welfare State. Britain and France 1914-1945 (Cambridge, 1993); Sainsbury, Gender, Equality, pp. 49 72; and Theda Skocpol, Protecting Soldiers and Mothers. The Political Origins of Social Policy in the United States (Cambridge, MA, 1992).

"Jane Lewis, "Gender and the Development of Welfare Regimes", Journal of European Social Policy, 2 (1992), pp. 159-173. 
Instead, she focuses on the ideological and political role of the Social Democratic party and argues that it was not until the late 1960s and early 1970s that successive Social Democratic governments consciously moved towards a dual breadwinner model. ${ }^{5}$

Lewis's divergent approaches to French and Swedish welfare state history points to the need for more developed analyses of the Swedish case. To understand the rise of the weak Swedish male breadwinner state, we need to pay more attention to economic and demographic developments as well as to actual policies enacted during the early period of welfare state institutionalization. In fact, Sweden and France experienced to some extent similar economic and demographic developments before World War II. As will be shown below, a closer examination of early Swedish social policies also reveals that Sweden - like France - was early marked by a comparatively weak adherence to the male breadwinner model. ${ }^{6}$

In this paper, I suggest an economic and demographic approach to the study of welfare state attitudes towards the male breadwinning system. This approach focuses on the male breadwinning system as an economic structure. It should be remembered that female participation in breadwinning activities does not necessarily imply female autonomy or emancipation. I designate Sweden as a weak male breadwinner state and the United States as a residual variant of the strong male breadwinner state.

In most recent feminist research on the rise of welfare states, a leading question has been to what extent political variables determine variations in welfare state development. ${ }^{7}$ My analysis of the American and Swedish cases takes account of some insights from this polity-centred approach, and I have also built to some extent on other theoretical approaches, such as the role of industrialization and class mobilization. ${ }^{8}$ However, my primary aim in this article is not to develop a broad explanatory framework, but rather to point to the hitherto largely neglected role of national reproductive experience in the gendering of welfare states.

S Compare Jane Jenson and Rianne Mahon, "Representing Solidarity: Class, Gender and the Crisis in Social-Democratic Sweden", New Left Review, 201 (September/October 1993), pp. 77-91; and Yvonne Hirdman, "Genussystemet", in SOU 1990: 44. Demolrati och makt i Sverige (Stockholm, 1990), pp. 73-112.

6ompare Sainsbury, Gender, Equality, pp. 63-67.

- For example Seth Koven and Sonya Michel, "Womanly Duties: Maternalist Politics and the Origins of Welfare States in France, Germany, Great Britain, and the United States, 1880-1920". The American Historical Review, 95 (1990), pp. 1076-1114; Pederson, Family, Dependence, and the Origins of the Welfare State; and Skocpol, Protecting Soldiers and Mothers.

For theoretical overviews, see for example ibid., pp. 11-62; and John B. Williamson and Fred C. Pampel, Old Age Security in Comparative Perspective (New York, 1993), pp. 5-19. 


\section{AN ECONOMIC AND DEMOGRAPHIC APPROACH TO WELFARE STATE DEVELOPMENT}

I suggest that conditions in the sphere of human reproduction have shaped state attitudes towards the male breadwinning system in decisive ways. In order to analyse the impact of reproductive conditions, we may distinguish between, on the one hand, a country's capacity to make investments in human reproduction, its capacity for reproductive investments, and, on the other hand, the specific reproductive challenges that occur during the formative period.

A country's capacity for reproductive investments is closely related to per capita income. If per capita income is high, the reproduction of the population can largely rely on a male breadwinning system. In this situation, it is possible to allocate large private resources to reproductive investments, and reproductive activities can be separated into specialized, typically female spheres of activity. When incomes are low, however, the amount of resources that can be spent on reproductive investments is more limited. Women will tend to share their time between productive and reproductive activities, often giving priority to the former, and men's role as providers will be less marked."

The term "reproductive challenges" refers to demographic changes that diminish a society's supply of labour power, either in absolute terms or in relation to dependent age groups. In Western welfare state history, emigration constitutes one such important reproductive challenge. Typically, people emigrate as young adults. When this happens, the national supply of labour power is immediately reduced. Low or falling fertility represents a less dramatic phenomenon, but when countries experience low or declining birth-rates there is reason to fear future labour shortages. An ageing population, finally, is a reproductive challenge that eventually affects all countries that go through the demographic transition. When the proportion of old people increases, the reproductive burden on the economically active population will weigh more heavily. ${ }^{10}$

How, then, does national reproductive experience affect state attitudes to the male breadwinning system? I suggest, first, that reproductive experience shapes living conditions and everyday practices, thereby fostering political demands and strategies with distinct class and gender characteristics. An ageing population, for example, might encourage demands not

- For this approach, compare Bussemaker and van Kersbergen, "Gender and Welfare States", p. 20.

${ }^{10}$ Low fertility and ageing, though not migration, have attracted substantial attention in welfare state research: see, for example, Gisela Bock and Pat Thane, Maternity and Gender Policies. Women and the Rise of the European Welfare States 1880s to 1950s (London, 1991), pp. 10-11; Peter H. Lindert, "The Rise of Social Spending, 1880-1930", Explorations in Economic History, 31 (1994), pp. 6-7 and 16-28; and Fred C. Pampel and John B. Williamson, Age, Class, Politics and the Welfare State, (Cambridge, NJ, 1989), pp. 59 and $165-168$. 
only for old age insurance and old age care but also for increased support to other reproductive activities strained by scarce resources, such as childcare. Second, reproductive experience affects state concerns about national strength and survival. Only so long as a nation's supply of labour power is perceived as satisfactory, in both quantity and quality, will human reproduction be seen as a purely private concem.

\section{THE UNITED STATES: THE RISE OF A RESIDUAL MALE BREADWINNER STATE}

The most distinctive feature of the United States around the turn of the twentieth century was its high capacity for reproductive investments. In 1913, the United States had the highest per capita income in the world. Only the United Kingdom and Australia came close to the American figure." Economic growth and urbanization proceeded rapidly. Industry, commerce and administration expanded at the expense of agriculture. ${ }^{12}$ However, inequality in wealth and income was also great. By the time of early welfare regime institutionalization, the relative economic distance between the middle ranks and the poor was probably greater in the United States than in almost any other industrial country. ${ }^{13}$

In this distinctive economic setting, signs of a strong male breadwinner system were to be found at an early date. In the eastern, most commercialized parts of the country, reproductive strategies of male breadwinning had already grown increasingly important in the 1820s and 1830s. By this time, rising numbers of urban middle-class women no longer needed to take an active part in family businesses, wage work or extensive home production of food and textiles. A discourse on motherhood, domesticity and gender difference unfolded, stressing women's private caring responsibilities, moral superiority and emotional capacities. According to influential opinion-makers, women and men should act in separate spheres. ${ }^{14}$ In other social settings, such as agriculture, male breadwinning practices were less developed, but even here norms of female domesticity were spreading. ${ }^{15}$

"Angus Maddison, Dynamic Forces in Capitalist Development. A Long-Run Comparative View (Oxford, 1991), pp. 6-7, table 1.1.

12 Ninth Census of the United States taken in the year 1870. Volume III, pp. 808-809; Thirteenth Census of the United States taken in the year 1910. Volume VIII, p. 238.

13 Jeffrey G. Williamson and Peter H. Lindert, American Inequality. A Macroeconomic History (New York, 1980), pp. 75-132; Lindert, "The Rise of Social Spending", pp. 26-28.

${ }^{14}$ Nancy F. Cott, The Bonds of Womanhood. "Women's Sphere" in New England, 17801835 (New Haven, 1977); and Mary P. Ryan, Cradle of the Middle Class. The Family in Oneida County, New York, 1790-1865 (Cambridge, MA, 1981).

${ }^{15}$ Jon Gjerde, The Migration from Balestrand, Nonway, to the Upper Middle West (Cambridge, MA, 1985), pp. 192-201; Joan Jensen, Promise to the Land. Essays on Rural Women (Albuquerque, 1991), pp. 11-21: Lena Sommestad and Sally McMurry, "Farm Daughters and Industrialization: A Comparative Analysis of Dairying in New York State 
Female labour force participation in the United States was comparatively low. By 1910, only 23.4 per cent of all adult American women including agrarian women - were in gainful occupations, while female participation rates in major European nations at the time exceeded 35 per cent. ${ }^{16}$ Among married European American women, only 6.5 per cent were registered as gainfully employed in $1920 .{ }^{17}$ In addition, American society was marked by a strong male breadwinner ideology. Although married women in lower-income families had in practice to contribute to the family economy - if not by wage work, then by taking in boarders, supplementing the limited incomes of wage earners, or by doing odd jobs for pay - this female economic contribution was seldom recognized in the social policy discourse. ${ }^{18}$

I suggest that the comparatively high capacity for reproductive investments in early twentieth-century America shaped state attitudes towards the male breadwinning system in decisive ways. Most importantly, high reproductive capacity served to diminish the demand for all sorts of state interventions in the sphere of reproduction. As argued by historian Daniel Levine, a deep-rooted perception of the United States as a land of plenty meant that most Americans saw poverty as something unnecessary, even among workers. It was believed that people should normally be able to manage critical states such as parenthood, sickness or old age without public support. Those who failed were seen as deviants to be cared for through philanthropy or poor relief, not through comprehensive systems of social security. ${ }^{19}$

Second, the great confidence in the male breadwinning system formed the basis for a gender-divided model of citizenship. In this model, men were regarded as independent breadwinners, normally capable of protecting themselves and providing for their families without public support. Women, on the other hand, were in principle to be protected and provided for by male breadwinners. Only if they lacked male protection, because they were widows or worked unprotected in factories, for example, were limited state interventions seen as legitimate in order to guarantee prevailing norms of motherhood and domesticity. This gender-divided model of citizenship had a profound impact on welfare thought in the United States. As noted by Alice Kessler-Harris, the recognition of women's

and Sweden, 1860-1920", Journal of Women's History (forthcoming, vol. 10, Summer 1998).

${ }_{16}$ Thirteenth Census of the United States taken in 1910. Volume $N$, p. 37; Bock and Thane, Maternity and Gender Policies, p. 16, table 0.2.

17 Teresa L. Amott and Julie A. Matthaei, Race, Gender and Work. A Multicultural Economic History of Women in the United States (Boston, 1991), p. 303, table 9.3.

18 Ibid., pp. 297-307; Jensen, Promise to the Land, pp. 11-21; Alice Kessler-Harris, Out to Work. A History of Wage-Earning Women in the United States (Oxford, 1982), pp. 108141; and by the same author, $A$ Woman's Wage (Lexington, 1990), pp. 57-80.

19 Daniel Levine, Poverty and Society. The Growth of the American Welfare State in International Comparison (New Bnunswick, NJ, 1988), pp. 15-23 and 151-179. 
gender-specific need for state protection only strengthened the widespread suspicion of state intervention. Male citizenship was equated with selfreliance and men of all classes tended to associate freedom from state intervention not only with independence, but also with manliness. ${ }^{20}$

Finally, high capacity for reproductive investments encouraged the belief that women should specialize in reproductive activities. An important expression of this belief was the early social policy ambition to provide American widowed mothers with "mothers' pensions". While the United States was a laggard in other fields of social policy, American states pioneered pensions for single mothers (primarily widows) as early as the 1910s. By 1930, mothers' pension laws had been passed by forty-four states. ${ }^{21}$

In a comparative perspective, the limited scope of public interventions in American social provision is indeed striking. With some exceptions, comprehensive programmes of social security or income maintenance were largely lacking up to the 1930s. The United States had neither sickness insurance nor old age insurance on the federal level. Public assistance was typically means-tested and directed towards the very poor. No labour regulations for male workers were passed other than special laws applying to particularly dangerous occupations. In addition, no extensive public services were provided in relation to caring activities or motherhood. Among the few successful programmes enacted before the New Deal was Workmen's Compensation, an insurance programme dealing with industrial injury, passed by forty-two states between 1911 and 1920.22

Instead, widespread prosperity provided the basis for voluntary structures of social provision, in particular philanthropy. Great numbers of wealthy Americans had the economic and temporal resources successfully to organize large-scale private support for the marginalized needy. This philanthropic movement was a multifaceted phenomenon. It developed into an inclusive voluntary grass-roots movement as well as into a business of benevolence with employed social workers, stretching from traditional charity to social case work. Cooperation with public institutions was widespread. $^{23}$

20 Kessler-Harris, "Gendered Interventions", pp. 3-22; and by the same author, "The Paradox of Motherhood. Night Work Restrictions in the United States", in Ulla Wikander, Alice Kessler-Harris and Jane Lewis (eds), Protecting Women. Labor Legislation in Europe, the United States, and Australia, 1880-1920 (Urbana, 1995), pp. 337-357; and Robyn Muncy, Creating a Female Dominion in American Reform 1890-1935 (New York, 1991), pp. 3-37.

"Skocpol, Protecting Soldiers and Mothers, pp. 3-11 and 424-479.

22 Michael B. Katz, In the Shadow of the Poorhouse. A Social History of Welfare in America (New York, 1986), pp. 113-205; Levine, Poverty and Society, pp. 151-179; James T. Patterson, America's Struggle Against Poverty 1900-1980 (Cambridge, MA, 1981), pp. 20-34; Skocpol, Protecting Soldiers and Mothers, pp. 3-11, 226-229 and 285-286.

${ }^{23}$ Robert H. Brenner, American Philanthropy (Chicago, 2nd ed., 1988), pp. 72-135; Frank Dekker Watson, The Charity Organization Movement in the United States. A Study in American Philanthropy (New York, 1922), pp. 65-443. 
Women played a crucial role in the institutionalization of the limited and gendered American male breadwinner state. Most importantly, middle-class women with plenty of time took on responsibility for vital reproductive activities both inside and outside their own families, such as childcare, poor relief, public health campaigns, and the operation of orphanages and playgrounds. They coordinated philanthropic activities in charity organization societies, engaged in philanthropic field work as "friendly visitors", or developed more radical altematives such as the settlement house movement. These activities reduced the demand for state interventions and encouraged the belief that domestic work and "social housekeeping" are intrinsically private and female duties. In addition, more reform-minded women engaged in social policy-making, primarily by lobbying for public interventions in favour of women only. They gathered in influential organizations, such as The General Federation of Women's Clubs, and they concentrated successfully on carrying through programmes of mothers' pensions, matemal and child welfare, and protective labour legislation for women. In the period from 1908 to 1920,39 states passed hour laws for women, 13 states passed minimum wage laws for women, and 16 states explicitly forbade female night work. It was rarer, however, for female reformers to extend their interventionist ambitions to include more extensive public support for the process of human reproduction. ${ }^{24}$

How, then, was this residual male breadwinner state influenced by our second explanatory factor, reproductive challenges, during the early, formative phase of welfare regime institutionalization? In brief, I suggest that the American tendency to rely on the private male breadwinning system was for a long time significantly strengthened by the comparative weakness of reproductive challenges (such as emigration, falling fertility and ageing). Only during temporary periods of military, economic or demographic crisis, such as World War I and the Depression, did problems of human reproduction for some time attract greater political attention. The breakthrough for old age security on the federal level, for example, came during the Depression, a period of temporary emigration and a growing proportion of elderly people in the population. ${ }^{2 s}$

24 Paula Baker, "The Domestication of Politics: Women and American Society, 17801920", in Linda Gordon (ed.), Women, the State and Welfare (Madison, 1990), pp. 55-91; Brenner, American Philanthropy, pp. 72-84; Kessler-Harris, "The Paradox of Motherhood", p. 338; Levine, Poverty and Society, pp. 28-36; Muncy, Creating a Female Dominion, pp. 3-211; Skocpol, Protecting Soldiers and Mothers, pp. 8-10, 95-96 and 321-524. For more radical outlooks among American female reformers, see Wendy Sarvasy, "Beyond the Difference Versus Equality Debate: Postsuffrage Feminism, Citizenship and the Quest for a Ferminist Welfare State", Signs, 17 (1992), pp. 329-362.

${ }^{25}$ Historical Statistics of the United States, Colonial Times to 1957. A Statistical Abstract Supplement, US Department of Commerce, Bureau of the Census (Washington DC, 1960), p. 8. Series A 20 and p. 10, Series A 84; Julian L. Simon, The Economic Consequences of Immigration (Oxford, 1989), pp. 31-35; Edward D. Berkowitz, America's Welfare State. From Roosevelt to Reagan (Baltimore, 1991), pp. 15-28. 
The great American confidence in the male breadwinning system was particularly encouraged by extensive immigration. Immigration peaked in the first decade of the twentieth century, when it accounted for almost 40 per cent of total population increase. It was dominated by men with a high rate of labour force participation, and - except during the World War I period - it remained important up to the mid-1920s. ${ }^{26}$

Immigration shaped American class and gender relations in significant ways. As regards state attitudes to the male breadwinning system, the most important effect was to reduce national interest in female labour and in more - or healthier - babies. With a steadily growing population and an abundant male labour supply, it was hard to get support for extensive public efforts to support childbearing and childraising or to help mothers combine their duties as workers and mothers. ${ }^{27}$ Only during World War I did demand for female labour rise considerably, and the war situation also opened up some possibilities for child welfare reform. As healthy children were increasingly regarded as a vital resource for the nation, female reformers could use temporary currents of patriotism and stateinterventionism to advance the cause of maternal and child welfare, a social policy effect of warfare well known from other countries. The result was the first federal programme of maternal and child welfare in the United States, the Sheppard-Towner Act (1921-1929). ${ }^{28}$

The lack of support for mothers and children is indeed one of the most striking features of early American social policy. In spite of extensive female activism and strong currents of maternalism, American reformers did not succeed in carrying through any universal programmes of maternal and child welfare. Only mothers in need could get support, and the programmes enacted were limited in scope. Under the 1921 Sheppard-Towner Act, for example, public nurses could offer maternal and infant health education but no direct services. For working mothers, there were no paid maternity leaves, and the issue of childcare provision did not attract much attention. The enactment of mothers' pension laws did for some time nurture more radical visions of social reform, but in reality benefits were small and meanstested, and only a minority of single mothers got any aid at all. ${ }^{29}$

${ }^{26}$ Historical Statistics of the United States, p. 62, Series 134; Simon, The Econonic Consequences of Immigration, pp. 22-34.

27 Alisa Klaus, "De-Population and Race Suicide: Matemalism and Pronatalist Ideologies in France and the United States", in Seth Koven and Sonya Michel, Mothers of a New World. Maternalist Politics and the Origins of Welfore States (New York, 1993), pp. 188-190. The boost to population growth caused by immigration was further consolidated by relatively satisfactory birth-rates (Historical Statistics of the United States, p. 23, Series B 19).

28 Muncy, Creating a Female Dominion, pp. 93-157.

29 Berkowitz, America's Welfare State, pp. 96-97; Gordon, Pitied But Not Entitled, pp. 3764; Kessler-Harris, "The Paradox of Motherhood", p. 337; Koven and Michel, "Womanly Duties", pp. 1085-1107; and Sonya Michel, "The Limits of Matemalism: Policies Towards American Wage-Eaming Mothers during the Progressive Era", in Koven and Michel, Mothers of a New World, pp. 277-320. 
When the Social Security Act of 1935 was passed, a new era of American social policy began. In a period of economic and demographic crisis, the need for more direct support for American breadwinners was recognized, and benefits such as unemployment insurance and old age insurance, tied to labour market attachment, were developed. As regards state attitudes to the male breadwinning system, however, little changed. The gendered, "two-channel" American welfare state took shape, built on earlier national experience. While men were increasingly covered by social insurance, most women got their benefits either as dependent wives to insured men or as recipients of public assistance. Mothers' pension programmes were followed by the more extensive Aid to Dependent Children (ADC) ${ }^{30}$ When we now turn to our second case, Sweden, we will discover a very different welfare state history.

\section{SWEDEN: THE HISTORICAL ROOTS OF A WEAK MALE BREADWINNER STATE}

In the early twentieth century, Sweden differed from the United States in two crucial respects. First, per capita income in Sweden was only half the American figure. Capacity for reproductive investments was low. ${ }^{31}$ Second, Sweden experienced great reproductive challenges, emigration and falling fertility, in the period up to the $1930 \mathrm{~s}^{32}$ The combination of poverty and reproductive challenges contributed to shaping a distinctive Swedish blend of social policies, marked by public intervention and comparatively gender-neutral solutions to problems of social provision. The outlines of an interventionist, weak male breadwinner welfare state were discernible at an early date.

Early twentieth-century Sweden has been characterized as poor and egalitarian. For all except a remarkably limited upper and middle class, living conditions were trying and economic distress was widespread even among small entrepreneurs and farmers. The majority of the population made their living as labourers or small farmers in the countryside. Industrialization was largely rural and still at an initial stage. In 1910, 70 per cent of the population resided outside towns and boroughs, and close to 50 per cent made their living from agriculture. ${ }^{33}$

${ }^{30}$ Berkowitz, America's Welfare State, pp. 1-38 and 96-97; Gordon, Pitied But Not Entitled, pp. 145-285; Barbara J. Nelson, "The Origins of the Two-Channel Welfare State: Workmen's Compensation and Mothers' Aid", in Gordon, Women, the State and Welfare, pp. 123-151; and Sainsbury, Gender, Equality, pp. 58-63, 81-84, 89-90 and 113-116.

${ }_{31}$ Maddison, Dynamic Forces, pp. 6-7, table 1.1. The estimations refer to 1913.

32 Historical Statistics of Sweden, vol. I (Stockholm, 1955), pp. 45-46, 68, tables B 2 and B 21.

${ }^{33}$ Gøsta Esping-Andersen, "Jämlikhet, effektivitet och makt. Socialdemokratisk välfärdspolitik", in Klaus Misgeld et al. (eds), Socialdemokratins samhälle (Stockholm, 1988), p. 224; Lennart Jörberg, "Structural Change and Economic Growth: Sweden in the 19th Century", in P.K. Brien (ed.), The Industrial Revolution in Europe, vol. 5 of The Industrial 
The low capacity for reproductive investments was particularly evident in the countryside. Around the turn of the twentieth century, average incomes in rural districts were generally too modest to permit any exclusively private solutions to problems of poverty, sickness, childbirth or old age. ${ }^{34}$ Instead, responsibilities of employers or household heads were complemented by state-directed intervention along traditional lines. Poor relief, long the most important type of social provision, was organized and financed by local authorities but regulated by national law. Medical care was organized partly by the state through a tax-financed scheme of district physicians, and partly by regional county councils with tax-raising powers, which were responsible for in-patient hospital services. In addition, stateeducated midwives employed by local authorities played a crucial role in offering maternal and medical services in rural districts. ${ }^{35}$ Only in more populated areas did strategies of self-reliance for some time develop more widely. Here, better-off entrepreneurs and employees could turn to the market by utilizing insurance companies and doctors in private practice, while workers organized their own sickness insurance funds. ${ }^{36}$

In contrast to the United States, Swedish society was heavily dependent on female labour, married and unmarried. There is ample historical evidence of the crucial role played by women in Swedish production, in particular within agriculture, and the difference between women's lot in Sweden and the United States is a recurrent theme in the emigration literature. By the tum of the twentieth century, important areas of production, most notably milking and dairying, were led almost exclusively by

Revolutions series (Oxford, 1994), pp. 411-454; Sven E. Olsson, Social Policy and Welfare State in Sweden (Lund, 1990), pp. 112-113; and Tom Söderberg. Tvả sekel svensk medeklass (Stockholm, 1972), p. 243, table 11. For income distribution, see Stein Kuhnle, "The Beginnings of the Nordic Welfare States: Similarities and Differences", Supplement, Special Congress Issue: The Nordic Welfare States, Acta Sociologica, 21 (1978), pp. 1720; and Alderdomsförsäkringskommittén, vol. I (Stockholm, 1912), pp. 66-68. Figures on urbanization and industrialization in Historical Statistics of Sweden, p. 21, table A 14; p. 29, table A 21.

34 Joakim Persson, "Convergence in Per Capita Income and Migration across the Swedish Counties 1906-1990 European Economic Review (forthcoming); and Älderdomsförsäkringskommittén, vol. IV (Stockholm, 1912), pp. 332-333, table 11.

3s Åke Elmér, Frän fattigsverige till välfärdsstaten (Stockholm, 1969), pp. 46-49; Torkel Jansson, "The Age of Associations. Principles and Forms of Organization Between Corporations and Mass Organizations. A Comparative Nordic Survey from a Swedish Viewpoint", Scandinavan Journal of History, 13, 4 (1988), pp. 326-327 and 334-339; Olsson, Social Policy, pp. 108-109; Sverker Oredsson, "Samhällelig eller enskild faltigvård?", Scandia, 37 (1971), pp. 175-215; Roger Qvarsell, "Mellan familj, arbetsgivare och stat". in Erik Amnå (ed.), Medmänsklighet att hyra? (Stockholm, 1995), pp. 19-22; and Christina Romlid, "Swedish Midwives and Their Instruments in the Eighteenth and Nineteenth Centuries", in Hilary Marland and Anne Marie Rafferty (eds), Midwives, Society and Childbirth: Debates and Controversies in the Early Modern Period (London, 1997), pp. 38-43. ${ }^{36}$ Rafael Lindqvist, Frän folkrorelse till vălfardsbyräkrati (Lund, 1990), pp. 39-55; Kajsa Ohrlander, I barnens och nationens intresse (Stockholm, 1992), pp. 148-152; SOS, Allmän hälso- och sjukvdrd är 1912 (Stockholm, 1914), pp. 84-89, table I. 
women. Agrarian women normally combined domestic duties with all types of physically demanding outdoor work - such as piling hay, picking potatoes, and even ploughing. Their status was tied to working capacity and physical strength, rather than to motherhood or domestic virtues. ${ }^{37}$

Outside agriculture, the role of married women in production was less conspicuous. However, norms of male breadwinning were most strictly followed within the small middle class. As in the United States, married working-class women typically contributed to the family economy through unregistered part-time jobs, such as industrial home work, cleaning and laundry work. They also complemented wage incomes with home production of consumption goods such as textiles, clothes, vegetables and potatoes. Considering the low income levels in Sweden, it is reasonable to believe that these female contributions were of greater importance to family survival in Sweden than in the United States. ${ }^{38}$

The extensive workload of Swedish women is reflected in the comparatively limited scope of female philanthropy. Although many Swedes early on engaged in voluntary associations such as temperance and missions, most regions lacked larger numbers of middle-class women prepared to invest time or money in extensive philanthropic projects. Only in towns and cities, where income levels were higher and the middle class more numerous, did Swedish female philanthropy develop into a more significant social force. Given that few people yet resided in urban areas, however, the overall impact of this early female activity long remained limited. It is telling that the most flourishing philanthropic movement eventually developed in Stockholm, where average incomes around the turn of the twentieth century were higher than anywhere else in Sweden at the time. ${ }^{39}$

${ }^{37}$ Mats Hellspong and Orvar Lofgren, Land och stad (Stockholm, 1974), pp. 243-247; Sommestad and McMurry, "Farm Daughters and Industrialization"; Ann-Sofie Kälvemark (Ohlander), "Utvandring och sjalvständighet", Historisk tidskrift, 2 (1983), pp. 154-173; Lars Olsson, "Den vita piskan", in Alf 0 . Johansson et al. (eds), Dagsverken. 13 essäer $i$ arbetets historia (Lund, 1995), pp. 49-66.

38 Lynn Karlsson, Mothers as Breadwinners. Myth or Reality in Early Swedish Industry?, Uppsala Papers in Economic History no. 39 (Uppsala, 1995), pp. 5-48; Lynn Karlsson and Ulla Wikander, "Om teknik, arbetsdelning och teknologi som formare av kvinnors - och mäns - arbetsvillkor", and Inger Jonsson, "Arbetssökande kvinnor göre sig icke besvär' ", both in Historisk tidskrift, 1 (1987), pp. 59-64 and 96-113; and Anita Nyberg, Tekniken - kvinnornas befriare? (Linköping, 1989), pp. 147-152.

${ }^{39}$ Birgitta Jordansson, " "Goda människor från Göteborg'. Fattigvård och vălgörenhet under 1800-talet", and Kerstin Thöm, "Föreningen för Välgörenhetens ordnande och bostadsfrågan", both in Marja Taussi Sjöberg and Tinne Vammen (eds), Pä tröskeln till välfärden. Valgörenhetsformer och arenor i Norden 1800-1930 (Stockholm, 1995), pp. 84103 and 129-151; and Ingrid Áberg, "Revivalism, Philanthropy and Emancipation. Women's Liberation and Organization in the Early Nineteenth Century", Scandinavian Journal of History, 13 (1988), pp. 399-420. Among all persons assessed for taxes in 1908, including tax on real estate, the average income in Stockholm was almost three times as high as in the countryside (Alderdomsförsäkringskommittén, IV, pp. 314-315, table 10, and pp. 332-333, table 11). 
Table 1. Rates of gainful employment among women in Sweden and the United States, 1920

\begin{tabular}{llll}
\hline & \multicolumn{2}{c}{ Sweden* } & The United States \\
& $\begin{array}{l}\text { Farm wives } \\
\text { included }\end{array}$ & $\begin{array}{l}\text { Farm wives } \\
\text { excluded }\end{array}$ & $\begin{array}{l}\text { European American } \\
\text { women }\end{array}$ \\
\hline All adult women & 54.2 & $(36.2)$ & 19.5 \\
Married women & 43.1 & $(3.9)$ & 6.5 \\
\hline
\end{tabular}

Sources: Amott and Matthaei, Race, Gender and Work, pp. 303, 305 (Tables 9-3, 9-4); SOS, Folkräkning 1920: V, pp. 10 (Table A), 61 and 68.

* For the inclusion/exclusion of farm wives, see the discussion of Swedish census data below.

Women's rates of gainful employment in Sweden and the United States in 1920 are compared in Table 1. Although it is difficult to make direct comparisons on the basis of the available statistics, the difference between the two countries is clear. In 1920, 36.3 per cent of Swedish adult women were registered as gainfully employed in the census, as compared to 19.5 per cent of all adult European American women. This official Swedish census figure underestimates the difference between the two countries, however, since the Swedish census, in contrast to the American one, did not distinguish between farm wives employed or not employed in outdoor farm work. All Swedish farm wives were formally registered as "wives".40 As observed by Anita Nyberg, this exclusion of farm wives conceals the historically extensive female participation in Swedish agriculture and is at variance with current census practice in rural, developing countries. Including all farm wives in the labour force produces a more accurate understanding of rates of gainful employment in Sweden. ${ }^{41}$ If this practice is followed, an even higher proportion - 54.2 per cent - of Swedish women can be regarded as gainfully employed in 1920. However, the inclusion of farm wives in the Swedish labour force has an even greater effect on married women's employment rates. If farm wives are included, 43.1 per cent of Swedish wives were gainfully employed in 1920, as compared to 6.5 per cent of European American wives. By contrast, if the census figures are taken at face value, the Swedish employment rate for married women is even lower than the corresponding American figure. ${ }^{42}$

Mass emigration from Sweden served further to reduce the national capacity for reproductive investments. In the period between 1851 and

${ }^{40}$ SOS, Folkrakning 1920, p. 11; Thirteenth Census of the United States taken in 1910. Volume $I V$, pp. 26-28.

4 Anita Nyberg, "Vad är förvärvsarbete?", Kvinnovetenstaplig tidskrift, 1 (1987), pp. 54-65.

12 It should be noted, however, that unregistered working wives of forestry and agricultural labourers are still not included (Nyberg, Tekniken - kvinnornas befriare?, pp. 147-151 and 154-155). 
1930, roughly 1.4 million people emigrated, most of them to the United States. Net emigration peaked in the 1880 s, but up to 1910 emigration was still extensive and it was not until the 1930s that emigration was replaced by modest immigration. The national loss of human resources caused by emigration was substantial, considering that the total Swedish population in 1900 amounted to only 5.1 million. ${ }^{43}$ The most problematic economic aspect of emigration was not the total loss of people, however, but the fact that most emigrants were young adults. During the 1861-1915 period, 65 per cent of emigrants were aged between 15 and 29. The effect of this was to reduce the number of economically active citizens in Sweden shouldering the burden of large cohorts of children and - in particular - the elderly. In 1910, 8 per cent of the Swedish population was 65 years of age and over, as compared to only 4 per cent in the United States. ${ }^{44}$

In addition, mass emigration influenced women's scope for reproductive activities by increasing a long-standing surplus of women in the Swedish population. During the 1851-1915 period, men constituted 55 per cent of emigrants, and in 1910 there were 105 women to every 100 men in Sweden, as compared to 94 women to every 100 men in the United States. ${ }^{45}$ A growing proportion of Swedish women remained unmarried, and the share of children born out of wedlock increased. ${ }^{46}$ In 1910 , only 46 per cent of the Swedish adult female population was married, as compared to 60 per cent in the United States. ${ }^{47}$ Among Swedish women born in the years 1885-1889, more than 50 per cent never married. ${ }^{48}$

Emigration had a profound impact on Swedish gender and class relations. Most importantly, the continued heavy dependence on female labour served to nurture an ambivalent, but largely permissive, attitude towards women's gainful work. Although assumptions of separate spheres were strongly advocated by some internationally well-connected opinionmakers, most notably the author Ellen Key, Swedish notions of femininity had in practice to be reconciled with the widespread necessity of lifelong

${ }^{43}$ Historical Statistics of Sweden, p. 63, table B 16, pp. 64-65, table B 17, and p. 68, table B 21.

" Per Gunnar Edebalk, "Fattigvårdsfolket och pensionsstriden 1912/13", Socialvetenskaplig tidstrift, 3 (1995), pp. 266, and 269; Historical Statistics of Sweden, p. 71, table B 4, and p. 22, table A 16; and Historical Statistics of the United States, p. 8, Series A 20 and p. 10, Series A 84.

4 Historical Statistics of Sweden, p. 5, table A 4, and p. 72, table B 25; Historical Statistics of the United States, p. 8, Series A 22-24.

${ }^{46}$ Gunnar Qvist, Konsten att blifia en god flicka (Stockholm, 1978), p. 102.

${ }^{47}$ Historical Statistics of Sweden, p. 28, table A 20, and Historical Statistics of the United States, p. 15. Series A 225.

${ }^{48}$ Robert Schoen and William L. Urton, Marital Status Life Tables for Sweden (Stockholm, 1979), pp. 16-17. 
female providing. ${ }^{49}$ Similarly, married women's crucial role in providing for their families shaped notions of housewifery as a breadwinning activity. According to the 1920 Marriage Act, both spouses were equally obliged to take care of home and children and to provide for the family. If the wife was not engaged in any gainful occupation, her domestic work was equated with male cash income as a contribution to family maintenance. ${ }^{\text {so }}$

More broadly, emigration contributed to a progressive national spirit of reflection and consensus. From the tum of the twentieth century, emigration was increasingly interpreted as a threat to the country, "draining it of its best and most valuable population".51 Political debates were skewed towards economic and social reform. Quite naturally, the flourishing and liberal United States - preferred by so many Swedish emigrants - was often referred to as a model for the future but, in practice, aspirations to stop emigration and catch up economically actually strengthened the Swedish interventionist tradition. Labour gained strength, and conservative and liberal opinion-makers launched visions of the nation as a "home", marked by social solidarity and security and vitalized by the combined effort made by the entire population to achieve modernization. Such visions anticipated the later well-known metaphor of "the people's home", coined in the 1920 s as a catchword for the social-democratic welfare state project. ${ }^{52}$

How, then, were Swedish state attitudes to the male breadwinning system shaped by the low capacity for reproductive investments and the challenge of emigration? Most importantly, traditional strategies of state intervention were encouraged. In the absence of a strong male breadwinning system, most people perceived public interventions in the sphere of human reproduction as necessary. Initially, the need for state support was judged most pressing in the countryside, but from the late nineteenth century, the challenge of emigration, an intensified process of industrialization and the rise of the labour movement conduced to strengthen interventionist tendencies in urban areas as well. From 1891, workers' sickness insurance funds were subsidized by the state, and in the following decades the parlia-

49 Christina Carlsson, Kvinnosyn och kvinnopolitik (Lund, 1986), pp. 249-277; Beata Losman, Kamp för ett nytt kvinnoliv (Stockholm, 1980); and Ulla Wikander et al., Det evigt kvinnliga (Stockholm, 1994).

so Karin Widerberg, Kvinnor, klasser och lagar (Stockholm, 1989), p. 71.

${ }^{31}$ Ann-Sofie Kalvemark (Ohlander), "Swedish Emigration Policy in an Intemational Perspective, 1840-1925", in Harald Runblom and Hans Norman (eds), From Sweden to America. A History of the Migration (Minneapolis, 1976), pp. 106-112 (quotation on p. 106).

32 Walter Korpi, "Den svenska arbetarrörelsens fơrutsättningar och strategier", in Per Thullberg and Kjell Östberg (eds), Den svenska modellen (Lund, 1994), pp. 16-19; Kälvemark (Ohlander), "Swedish Emigration Policy", pp. 106-112; Bo Sträth, "Industriborgerskapets roll i den svenska samhällsomvandlingen", in Knut Kjeldstadli et al. (eds), Formeringen av industrisamfunnet i Norden fram til 1920, TMV skriftserie, 5 (Oslo, 1994), pp. 29-46. 
ment passed several laws of national significance: the Factory Inspection Act (1889), the Old Age and Invalidity Pension Act (1913), the Occupational Injury Insurance Act (1916), the new Poor Relief Act (1918), the Eight-hour Law (1920), the Child Welfare Act (1924), and legislation establishing a state-subsidized Unemployment Insurance (1935). ${ }^{33}$

Second, the national reproductive experience encouraged a comparatively gender-neutral approach to problems of labour protection and family maintenance. This gender neutrality was first reflected in labour legislation. In contrast to the situation in the United States, Swedish men and women were normally covered by the same protective labour laws. Public protection was not specifically associated with femininity. The 1909 Night Work Prohibition for women, inspired by foreign examples, was the only major exception. ${ }^{34}$ More importantly, Sweden also pioneered citizen-based entitlements which included women and men within the same structures of social provision and, in line with this gender-neutral approach, the role of mothers and married women as breadwinners was clearly emphasized.

The first decisive step towards a gender-neutral model of social citizenship in Sweden was taken with the passage of the 1913 Old Age Act. This Act, shaped by farmers' demand for a "people's insurance", introduced into Swedish social policy the principle of universal entitlements. It gave only small pension benefits, but all Swedish citizens - including married women - were covered by the same combined contributory and taxfinanced scheme. ${ }^{55}$ Women received lower benefits in relation to their contributions than men, but the principle of universalism nevertheless indicated that the unpaid work of married women was in principle deemed to be of comparable value to the national economy as the wage work of unmarried women. ${ }^{56}$ Three years later, in 1916, the citizen-based approach of the Old Age Act was confirmed by a similarly broad ambition in the progressive and innovative Occupational Injury Insurance Act. In contrast to Workmen's Compensation in the United States, the Swedish occupa-

\$3 Per-Gunnar Edebalk, "1916 års olycksfallsförsäkring”, Scandia, 59, 1 (1993), pp. 116119; and by the same author, "Fattigvårdsfolket", pp. 266-267, 269; Lindqvist, Frän folkrörelse till valfardsbyräkrati, pp. 51-53; Ohrlander, I barnens och nationens intresse, pp. 148-152; Olsson, Social Policy, p. 109; and SOS 1971: 42, Försäkring och annat kontant stöd vid arbetsläshet (Stockholm, 1971), pp. 70-72.

s4 This law was passed in the wake of widespread female opposition, see Carlsson, Kvinnosyn och kvinnopolitik, pp. 170-175; and Lynn Karlsson, "The Beginning of a 'Masculine Renaissance': The Debate on the 1909 Prohibition against Women's Night Work in Sweden", in Ulla Wikander et al., Protecting Women, pp. 252-253.

ss Anders Berge, "Socialpolitik och normgivning i Sverige 1871-1913", Arkiv, 63-64 (1995), pp. 76-89; Olsson, Social Policy, pp. 83-89, 93-97; and Edebalk, "Fattigvårdsfolket", pp. 266-275.

36 The lower benefits awarded to women were widely questioned at the time - also in parliament - but to no avail. See Kerstin Abukhanfusa, Piskan och moroten (Stockholm, 1987), pp. 28-45; Älderdomsförsäkringskommittén, pp. 65-66 and 79-81. 
tional insurance covered a major part of the labour market, including female sectors such as domestic service. ${ }^{57}$

Another crucial step towards a gender-neutral model of citizenship was the passage of the 1918 supplement to the Old Age Act. This supplement stated that poor, single mothers were to be entitled to child supplements from the public pension system, but only if they were permanently unable to work. The Swedish state thus explicitly demanded that single mothers give priority to breadwinning over motherhood. In line with the genderneutral stance towards breadwinning duties, moreover, child supplements were not designed as a benefit confined to mothers, but as a form of support for parents of both sexes. Low-income couples and widowers incapable of working were also entitled to support. A similarly genderneutral attitude marked the 1916 occupational injury insurance, which gave life annuities to widowers as well as to widows. ${ }^{58}$

As in the United States, middle-class women in Sweden were active in shaping early social policies. Their attitudes and strategies were somewhat different, however. Without backing from extensive female grass-roots organizations of the type prevalent in the United States, leading Swedish female reformers chose instead to cooperate with male opinion-makers, politicians and administrators. Their vision of a better future was related less closely to an expanding female sphere than to a future society in which male rationality and female empathy were to be fused and combined. ${ }^{59}$ It is telling that Swedish female reformers did not follow the example of their American sisters in their intense lobbying for special labour legislation for women. Although Swedish middle-class reformers were profoundly influenced by the strong international movement calling for special protection of working women, and in principle supported its basic ideas, they did not work actively for any restrictive measures to regulate women's factory work. As shown by Lynn Karlsson, they chose instead to concentrate on other labour market problems, primarily the sweated conditions in home industry, and in this endeavour they did not explicitly use gender in arguing for regulations. In spite of the fact that women predominated in home industry, women's special need of protection was overshadowed by concern for workers of both sexes. ${ }^{60}$

It is clear that the gender-neutral stance of early Swedish social policies long reflected poverty and exploitation rather than emancipatory ambitions. In particular, women were given little help to combine wage work

57 Edebalk, "1916 års olycksfallsförsäkring", p. 117.

58 Ibid., p. 117; Ảke Elmér, Folkpensioneringen i Sverige (Malmö, 1960), pp. 49-54; SFS 1918: $449, \S 6$ and $\$ 33$.

39 The leading, gender-integrated Swedish social reform organization was Centralforbundet för Socialt arbete (CSA), see Centralforbundet för socialt arbete 1903-1928 (Stockholm, 1928), pp. 13-43; Kajsa Ohrlander, "Moderniserande kvinnlighet - gammal manlighet". Arkiv, 63-64 (1995), pp. 45-67; and Olsson, Social Policy, pp. 64-67.

so Karlsson, "The Beginning of a 'Masculine Renaissance" ", pp. 245-246. 
and motherhood. Maternity leave, for example, was compulsory in industry from 1901, but it was not until 1931 that mothers on leave received any financial support. ${ }^{61}$ As for childcare, crèches or day-care centres were rare before World War II, even in urban areas, and public support for childcare developed only slowly. If single mothers could not arrange daily care for their children, they had to send them away to relatives, often in the countryside, or were forced to board them out as foster children. It was not until the mid-1950s that children in day-care centres outnumbered foster children in Sweden. ${ }^{62}$

It is interesting to note, however, that the Swedish state chose at an early date to intervene in the private family sphere in ways that to some extent challenged patriarchal family power. This challenging state attitude was nurtured in particular by the threat of emigration, and it anticipated later population and equality policies. Many early reformers viewed the misery of Swedish children as a key obstacle to economic advance and national greatness. Male insobriety, brutality and neglect of home and family were seen as severe threats to national progress, and the need to protect women and children from the destructive effects of irresponsible masculinity came to motivate several legislative measures. From 1917, for example, the state backed the claims of mothers for economic support from the fathers of their children, and youth officers were appointed to look after the interests of single mothers and their children. Later programmes of maternity grants, advanced maintenance allowances, maternal care, universal family allowances, and universal maternity insurance enacted in the 1930s, 1940s and 1950s would focus on mothers and children in similar ways. Benefits were provided directly to the mothers. ${ }^{63}$

The -1930 s mark the transition to a new era. In this period, Sweden could well have moved towards a male breadwinner model in social provision. Average incomes were rising, and the ideological tide turned towards domesticity. Instead, a sharp decline in birth-rates helped to confirm the gender-neutral approach to social citizenship. Birth-rates in Sweden declined from 24 in 1920 to 15 in 1930, reaching an international low of only 14 in $1934 .^{64}$

61 Ann-Sofie Ohlander, "The Invisible Child? The Struggle For a Social Democratic Family Policy in Sweden, 1900-1960s", in Bock and Thane, Maternity and Gender Policies, p. 60.

${ }^{62}$ Anita Nyberg, "Bamomsorgen. Ett kvinligt nollsummespel eller?", in Amnå, Medmansklighet att hyra?, pp. 47-82.

${ }^{63}$ Teresa Kulawik, "Moderskapspolitik i Sverige och Tyskland i början på 1900-talet (1900-1930) - en skiss", in Är Habermas intressant för forskning om kvinnor och den offentliga sektorn? (Stockholm, 1991), pp. 34-37; Sainsbury, Gender, Equality, pp. 101103 and 190-194; Ohlander, "The Invisible Child?", pp. 60-72; Ohrlander, I barnens och nationens intresse, pp. 62-91; idem, "Moderniserande kvinnlighet", pp. 50-67; and Gena Weiner, De raddade barnen (Falkenberg, 1995), pp. 12-25 and 123-261.

of Allan Carlsson, The Swedish Experiment in Family Politics. The Myrdals and the Interwar Population Crisis (New Bnunswick, NJ, 1990), pp. 6-26; Ann-Katrin Hatje, Befolkningsfrägan och välfärden (Stockholm, 1974), pp. 7-8; Historical Statistics of Sweden. I, 
As in other European countries experiencing falling birth-rates, Sweden responded by enacting maternalist social policy measures such as maternity grants, marriage loans, free natal care and free deliveries (1937). The most distinctive feature of Swedish population policy, however, was the clear recognition of women's rights. With their influential book Crisis in the Population Question, Gunnar and Alva Myrdal succeeded in raising the population question as a starting-point for radical social reform policies aimed at influencing population growth in terms of both quantity and quality. They also argued, however, that higher birth-rates must be accompanied by freedom of choice for women (access to contraceptives), and that population policies must acknowledge employed mothers as a "social fact". Reforms should not support a male breadwinning system but give mothers - single or married - direct support for the costs associated with motherhood and caring and allow them to combine work and family without penalties. ${ }^{65}$

Gunnar and Alva Myrdal's standpoint on women's rights certainly sprang from Alva's feminist perspective, but it also mirrored the longstanding tradition of female breadwinning in Sweden. Although Alva Myrdal was more radical than most of her contemporaries, there was broad support for women's right to work in Swedish society at the time. This support was clearly revealed in the debates following proposals made by individual MPs in parliament in the wake of the Depression, suggesting that married women should be banned from working. In contrast to the situation in the United States, where women's organizations were split on this issue and most unions defended the family wage, all major women's organizations in Sweden united in their opposition to the proposal. The trade union movement eventually joined them. In 1939, a law was finally passed making it illegal to fire women by reason of marriage, pregnancy or childbearing if they had worked two years or more in a job. This piece of legislation marked the close of the early welfare state era and, seen in a long-term perspective, served as a bridge to the later rise of more explicit equality policies initiated in the late $1960 \mathrm{~s} .{ }^{66}$

What happened, then, in the intermediate period up to the 1960s? All in all, these decades of persistent economic growth and increased social spending reveal more ambivalent Swedish state attitudes to the male breadwinning system. On the one hand, the basically gender-neutral, citizen-based approach of the pre-war era was clearly confirmed and

pp. 45 and 46, table B 2; and Maddison, Dynamic Forces, p. 190, table A.2, and p. 234 , table B.3.

6s Carlsson, The Swedish Experiment, pp. 89 and 172-174; Hatje, Befolkningsfragan och vallfärden, pp. 32-37 and 237-245; Gunnar Myrdal, Population. A Problem for Democracy (Cambridge, MA, 1940), pp. 3-225; Sainsbury, Gender, Equality, p. 101.

${ }_{66}$ Barbara Hobson, "Feminist Strategies and Gendered Discourses in Welfare States: Married Women's Right to Work in the United States and Sweden", in Koven and Michel, Mothers of a New World, pp. 396-429. 
developed, for example in the introduction of universal flat-rate pensions (1946) and in the passage of a citizen-based sickness and maternity insurance (1955). On the other hand, some policies in support of a male breadwinning system also emerged. Wife supplements, for example, were added to the unemployment insurance during the 1941-1964 period (along with child supplements, 1941-1973). Similarly, when the old age pension arrangements were reformed in 1946, wife supplements and means-tested pensions for widows aged 55 and over were introduced. The recognition of women's rights as wives reached its height in the early 1960 s, when widows became entitled to pensions without means-testing at the age of only $36 .^{67}$ All in all, however, these post-war elements of a malebreadwinner model in Swedish social provision were limited in scope and, from the 1970 s onwards, they were gradually eliminated.

\section{CONCLUSION}

Both in the United States and in Sweden modern welfare state formation commenced around the turn of the twentieth century. Swedish as well as American reformers were part of an internationally wide-ranging movement for social reform. At the national level, however, debates and institutional choices were shaped by strikingly different reproductive conditions. The residual American male breadwinner state has its historical roots in a society marked by economic prosperity and immigration. An abundance of wealth and labour was the basis for a strong confidence in the male breadwinning system. The Swedish weak male breadwinner state, by contrast, grew historically out of shared experiences of poverty and national backwardness, combined with dramatic reproductive challenges: in particular emigration, and later declining fertility. Strained reproductive conditions encouraged the belief that extensive state interventions were needed in the sphere of reproduction, and social policies recognized women's duties as both breadwinners and mothers.

Compared to those in the United States, Swedish state ${ }_{\downarrow}$ attitudes to the male breadwinning system were already distinctive in the early period of welfare state institutionalization, prior to the 1930s. First, the Swedish state was more strongly inclined to intervene in the sphere of reproduction. This interventionist attitude, which reflects the idea that human reproduction is a national concem, was an important prerequisite for the later adoption of a dual breadwinner model.

Second, Sweden early developed a citizen-based, universal approach to problems of social provision. With regard to labour protection and programmes of maintenance, this universal approach was largely gender-

${ }^{67}$ Edebalk, Arbetslöshetsförsäkringen, p. 21; Elmér, Folkpensioneringen, pp. 80-81; Sainsbury, Gender, Equaliry, pp. 63-67 and 190-194; SOS 1971; 42, pp. 73 and 208-210; Widerberg, Kvinnor, klasser och lagar, pp. 123-125. 
neutral. Men as well as women were covered by protective labour legislation, and the introduction of citizen-based entitlements served to underline the basic similarity between married and unmarried women, and between women and men. With regard to maternal and child welfare, the citizenbased approach resulted in benefits targeted at children and mothers, either supplied in kind or paid to the mothers. Increasingly, these benefits were designed as universal entitlements. All in all, the citizen-based structure of social provision served to weaken the position of the male breadwinner.

Finally, early Swedish state attitudes towards single mothers and married women were marked by the primacy of breadwinning. The Swedish state recognized female breadwinning as a duty, and eventually also as a right. This emphasis on female breadwinning points to the modern Swedish welfare state, in which women's participation in the labour force is strongly encouraged.

According to Bo Rothstein, there are formative moments in political history when the enactment of new policies has a particularly strong impact on subsequent policy-making. Such formative moments are marked by challenging new economic and social conditions which extend freedom of action. ${ }^{68}$

I would suggest that the decades up to World War II constituted such a formative moment in Swedish welfare state history. During this period, Swedish politicians responded in innovative ways to dramatic economic and demographic challenges, and went a long way towards institutionalizing a comparatively gender-neutral model of citizenship. This development contrasted not only with the gender-divided approach prevalent in the contemporary United States, but also with the developing genderdivided structures of citizenship in neighbouring European welfare states, such as Britain, Germany and the Netherlands.

Further surveys and case studies are needed in order to explore the merits and limitations of an economic and demographic approach to welfare state formation. The most urgent task would be to compare the American and Swedish cases with strong male breadwinner states in Europe, such as Britain and the Netherlands, and with other modified or weak male breadwinner states, such as France. Britain stands out as a particularly interesting case. In the early twentieth century, per capita income in Britain was the highest in Europe, but - in contrast to the United States Britain was experiencing lagging economic growth and reproductive challenges such as emigration, falling fertility and ageing. Similarly, the Netherlands and France have combined divergent levels of national income with strikingly varied reproductive experiences.

Bo Rothstein, Den korporativa staten (Stockholm, 1992), pp. 17-20. Compare Skocpol, Protecting Soldiers and Mothers, pp. 57-60. 